\title{
Multicriteria analysis in the selection of urban highway alignment alternatives with application of the analytic hierarchy process: an environmentally sustainable approach
}

\author{
M. V. Lisboa \& J. Waisman \\ Department of Transportation Engineering, \\ Escola Politécnica da Universidade de São Paulo, Brazil
}

\begin{abstract}
This paper contains the proposition of a methodological process to be used during the planning phase of urban highways. It refers to a multicriteria analysis tool which selects the best route for a future highway considering not only geometrical engineering topics, most often used for highways definitions, but also important issues for modern society, such as environmental ones. This methodology was applied on the study of alignment alternatives of Sao Paulo's Ring Road, through interviews with some members of society and application of the Analytic Hierarchy Process.

Keywords: decision making, road alignment, analytic hierarchy process, sustainable environment.
\end{abstract}

\section{Introduction}

The concern about environmental issues has increased as the search for sustainable development continues. It has brought the need for an alignment alternative study of a road project to be accomplished based on coherence and quality. Emphasis on environmental aspects during alignment alternatives studies is considered, by technicians and consultants of developed countries, the most correct and economic way to assure a good road enterprise (McCormack [7]).

The defining process of the best alignment for a future urban highway can be considered one of the most important and delicate stages for its success. Therefore, a road enterprise characterized by its multidisciplinary aspects needs 
to pass through detailed analysis, based on a multicriterial decision aid method, which will assure to the entrepreneur and society involved in the implementation process the rank of alignment alternative proposals, indicating the most secure solution to guarantee an Environmental Licensing to be detailed and implemented successfully (Lisboa [5]).

\section{Decision making process}

This paper is based on the multicriterial decision aid method process, developed by Prof. Thomas Saaty from the University of Pennsylvania, named Analytic Hierarchy Process - AHP, showing a preliminary and strategic evaluation of social and environmental impacts. On transport and environment fields the AHP method is often mentioned in many bibliographical references (Gomes and Lima [3]; Rabbani and Rabbani [11]; Kalamaras et al. [4]; Ramanathan [12]; Zhu and Dale [14]).

Initially, the AHP is based on a hierarchic structure of objectives, criteria/indicators and alternatives considered in the study. Then, according to determined groups in the hierarchic structure, the pairs of criteria/indicators are compared, considering the importance of each criterion/indicator, related to the objective of the analysis, and pairs of established comparison matrices.

\section{Proposed model: definition of criteria and indicators of analysis and evaluation}

Some (Saaty apud Morita [8]) consider that the most important task during the analysis decision is the choice of relevant factors. Searching for a theoretical coherence according to the real needs of the decision making process in the evaluation and selection of highways alignment alternatives, the model proposed by Lisboa [5] is shared on three stages.

The first stage analyzed 7 previous experiences, where the selection of the road alternatives was accomplished considering the environmental aspects. This analysis allowed the choice of the most significant criteria and indicators, or the ones that best represent the various aspects that directly or indirectly influence the quality and success of a road enterprise. From the analysis of these studies, it was also possible to establish the criteria and indicators considered most relevant to support the methodology proposed in this paper, considering the multicriteria ordered in hierarchic levels.

Considering the peculiarities of AHP and the available software (Expert Choice), the definition and organization of selected criteria and indicators should be done in order to reduce the amount of judgments between pairs of criteria/indicators ( 85 judgments in this case), to prevent delays and lack of interest. These must be ordered in a hierarchical structure with a maximum of four levels. It is relevant to point out as well that for each group of $n$ indicators, there must be a total of $n .(n-1) / 2$ comparative judgments.

The second stage applies a technique called "brainstorming" where the first set of objectives, criteria and indicators was analyzed by technicians and 
specialists on road engineering and environment fields. As a result of this stage, the number of total judgments was reduced to 36. In the third stage, the Final Set of Criteria and Indicators of analysis and evaluation was defined based on the set developed on the second stage and considering the availability of data for application of the model, as the data base for this study case (DERSA [1]) did not fulfill the criteria and indicators as previously.

The proposed model was applied in three segments of the Northern section of Mario Covas Ring Road, using the criteria and indicators from table 1, as follows. This final configuration of the criteria and indicators defines a total of 27 judgments.

\section{Application of the proposed model: study case}

The segments analyzed on the highway represent Mario Covas Ring Road, an enterprise containing multiple objectives, whose main function is to divert through traffic and cargo vehicles from the urban central areas of Sao Paulo's metropolitan region. Figure 1, below, illustrates the alignment alternatives for the three road segments analyzed in this study.

Once the alignment alternatives were defined, the quantitative values related to the criteria and indicators defined in table 1 were surveyed. After this stage, the relative judgments will be carried out among the established pairs of criteria and indicators.

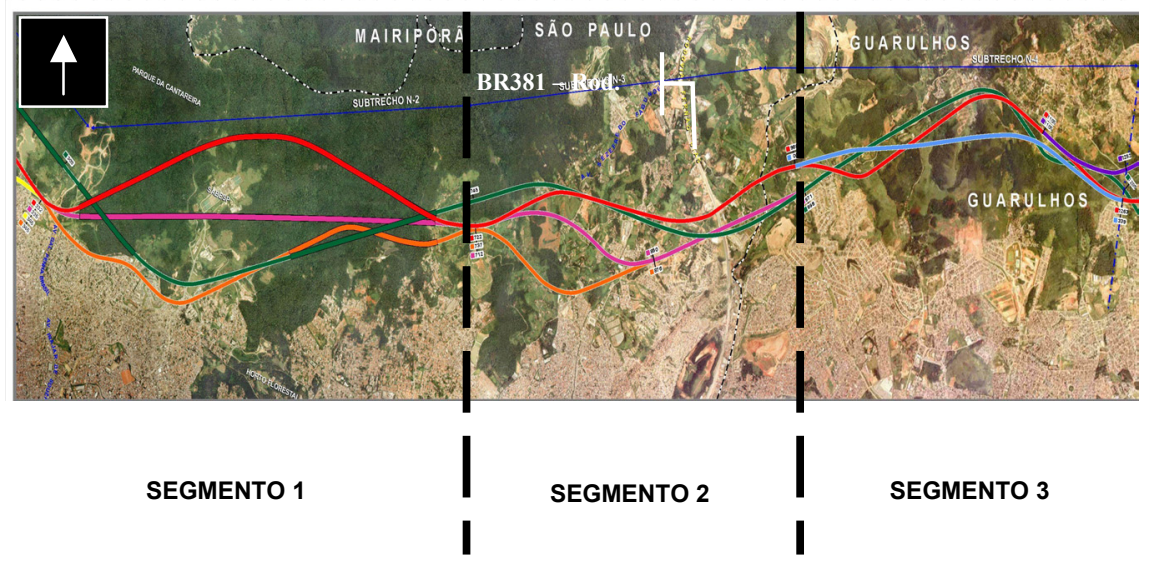

Figure 1: $\quad$ Alignment alternatives to be analyzed (DERSA [1]).

Based on the experience of highways implementation by governments and concessionaires companies and, according to Lopez [6], the following relation involves the 14 main sectors of society which, direct or indirectly, participate and/or are affected by the implantation of a new highway: community, NGO's, social entities, politicians, justice, university, press, environmental organizations, municipal agencies, entrepreneur, consultants, financial agents, highways concessionaires and contractors. 
Table 1: $\quad$ Final set of criteria and indicators.

\begin{tabular}{|c|c|c|c|}
\hline Criteria & \multicolumn{2}{|r|}{ Indicators } & \multirow[b]{2}{*}{ Units } \\
\hline Level 1 & Level 2 & Level 3 & \\
\hline $\begin{array}{l}\text { Economic } \\
\text { aspects }\end{array}$ & \multicolumn{2}{|c|}{$\begin{array}{l}\text { Implementation cost }(\text { construction }+ \\
\text { expropriation }+ \text { relocation }+ \text { operational) }\end{array}$} & $\mathrm{R} \$$ \\
\hline \multirow{5}{*}{$\begin{array}{l}\text { Construction } \\
\text { aspects }\end{array}$} & \multirow{3}{*}{$\begin{array}{l}\text { Surface } \\
\text { works }\end{array}$} & favorable areas & $\%$ of length surface works \\
\hline & & areas with some restrictions & $\%$ of length surface works \\
\hline & & areas with severe restrictions & $\%$ of length surface works \\
\hline & \multirow{2}{*}{$\begin{array}{l}\text { Special } \\
\text { works }\end{array}$} & bridges and viaducts & quantity \\
\hline & & tunnels & $\%$ of length with tunnel \\
\hline \multirow{4}{*}{$\begin{array}{l}\text { Operational and } \\
\text { traffic safety } \\
\text { aspects }\end{array}$} & \multirow{2}{*}{$\begin{array}{l}\text { Through } \\
\text { traffic }\end{array}$} & minimum curve radius & $\begin{array}{l}\% \text { of min.curve radius } \\
\text { length }\end{array}$ \\
\hline & & maximum grade & $\%$ of max.length of grade \\
\hline & \multicolumn{2}{|l|}{ Local traffic } & $\begin{array}{l}\text { number of blocked local } \\
\text { streets } / \mathrm{km}\end{array}$ \\
\hline & \multicolumn{2}{|c|}{ Pedestrian traffic } & $\begin{array}{l}\% \text { of extension of urban } \\
\text { area }\end{array}$ \\
\hline \multirow{9}{*}{$\begin{array}{l}\text { Environmental } \\
\text { aspects }\end{array}$} & \multirow{3}{*}{$\begin{array}{l}\text { Urban land } \\
\text { use impacts }\end{array}$} & $\begin{array}{l}\text { expropriations of productive } \\
\text { units }\end{array}$ & area in $\mathrm{m}^{2}$ \\
\hline & & expropriations of houses & household units \\
\hline & & relocation of population & number of families \\
\hline & \multirow{3}{*}{$\begin{array}{l}\text { Rural land } \\
\text { use } \\
\text { Impacts }\end{array}$} & native vegetation & area in $\mathrm{m}^{2}$ \\
\hline & & $\begin{array}{l}\text { road on areas of reforesting, } \\
\text { pasture and agriculture }\end{array}$ & area in $\mathrm{m}^{2}$ \\
\hline & & parks crossings & area in $\mathrm{m}^{2}$ \\
\hline & \multirow{3}{*}{$\begin{array}{l}\text { Physical } \\
\text { environment } \\
\text { impacts }\end{array}$} & water resources interference & $\begin{array}{l}\text { number of water } \\
\text { streams } / \mathrm{km}\end{array}$ \\
\hline & & air quality impacts & $\begin{array}{l}\% \text { of maximum slope } \\
\text { extension }\end{array}$ \\
\hline & & $\begin{array}{l}\text { noise } \\
(50 \mathrm{~dB}(\mathrm{~A}) \text { and } 100 \mathrm{~dB}(\mathrm{~A}))\end{array}$ & $\begin{array}{l}\text { urbanized area in } \mathrm{m}^{2} \\
\text { exposed to noises }\end{array}$ \\
\hline
\end{tabular}

According to the rules of AHP, established in Expert Choice [2], a reason taken for a decision made by a group of people, and not only by one individual, is the great variety of perspectives and ideas that each participant brings to the process of decision making. So, it is useful to discuss as many ideas as possible, for evaluation and prioritization in groups.

To obtain the particular judgment of each individual, this study took individual interviews with members of some groups of society. Then, these individual judgments were aggregated, resulting in a common opinion of each group interviewed.

From 14 selected groups, only one, Justice, did not have a representative interviewed, due to the lack of time to schedule its realization. So, 34 interviews composed the opinion of 13 groups of members of society. The whole process, from initial contacts, scheduling and interviews, took a period of approximately one month. 
The judgment of criteria and indicators was based on their importance relative to the objective of the proposed model: choice of the best alignment alternative to a highway that crosses an urbanized area - in this study case, three segments of the Northern section of Mario Covas Ring Road. The importance of each criteria/indicator related to the objective was considered, in pairwise comparisons, which criteria/indicator would be more critical, or desirable to be lower. Afterwards, the interviewees should establish a relation of the importance intensity, as shown in table 2 (Saaty [13]).

Table 2: $\quad$ Correlation of the judgment factors.

\begin{tabular}{ccc}
\hline Importance relation & AHP factors & Adapted factors \\
\hline Same importance & 1 & 0 \\
\hline Little more important & 3 & 2 \\
\hline more important & 5 & 4 \\
\hline Much more important & 7 & 6 \\
\hline Extremely more important & 9 & 8 \\
\hline
\end{tabular}

Table 3: $\quad$ Pairwise comparison matrices relationship.

\begin{tabular}{|c|c|c|c|}
\hline Matrix & $\begin{array}{l}\text { Order } \\
(\mathrm{n} \times \mathrm{x})\end{array}$ & Elements & $\begin{array}{l}\text { Number of } \\
\text { judgments }\end{array}$ \\
\hline \multirow{3}{*}{1 - "Surface works" } & \multirow{3}{*}{$3 \times 3$} & Favorable areas & \multirow{3}{*}{3} \\
\hline & & Areas with some restriction & \\
\hline & & Areas with severe restrictions & \\
\hline \multirow{3}{*}{$\begin{array}{l}2 \text { - "Operational and } \\
\text { traffic safety aspects" }\end{array}$} & \multirow{3}{*}{$3 \times 3$} & Through traffic & \multirow{3}{*}{3} \\
\hline & & Local traffic & \\
\hline & & Pedestrian traffic & \\
\hline \multirow{3}{*}{$\begin{array}{l}3 \text { - "Urban land use } \\
\text { impacts" }\end{array}$} & \multirow{3}{*}{$3 \times 3$} & Expropriation of productive unit & \multirow{3}{*}{3} \\
\hline & & Expropriation of household & \\
\hline & & relocation of population & \\
\hline \multirow{3}{*}{$\begin{array}{l}4 \text { - "Rural land use } \\
\text { impacts" }\end{array}$} & \multirow{3}{*}{$3 \times 3$} & Native vegetation & \multirow{3}{*}{3} \\
\hline & & Reforesting, pasture/ agriculture & \\
\hline & & On-level park crossings & \\
\hline \multirow{3}{*}{$\begin{array}{lll}5 & - & \text { "Physical } \\
\text { environment impacts" }\end{array}$} & \multirow{3}{*}{$3 \times 3$} & Water resources interference & \multirow{3}{*}{3} \\
\hline & & Air quality impacts & \\
\hline & & Noises & \\
\hline \multirow{3}{*}{$\begin{array}{l}6-\text { "Environmental } \\
\text { aspects" }\end{array}$} & \multirow{3}{*}{$3 \times 3$} & Urban land use impacts & \multirow{3}{*}{3} \\
\hline & & Rural land use impacts & \\
\hline & & Physical environment impacts & \\
\hline \multirow{4}{*}{7 - "Main aspects" } & \multirow{4}{*}{$4 \times 4$} & Economics aspects & \multirow{4}{*}{4} \\
\hline & & Constructive aspects & \\
\hline & & Operational and traffic safety aspects & \\
\hline & & Environmental aspects & \\
\hline
\end{tabular}

After calculation of the average judgments per group and all interviewed members, it was necessary, for insertion of judgment data on Expert Choice, for the correlation of the resultant adapted calculations of the arithmetic averages to the judgment factors of the AHP, as shown on table 3. So, the software Expert 
Choice was fed with all judgments obtained: 34 individual judgments, 13 average group judgments and 1 average judgment of all interviewed members.

\subsection{Consistency evaluation}

After insertion of data judgments into software, the determination of the Consistency Ratio - CR of the matrices of the resulting judgments must be checked. Considering that only matrices containing three or more elements are exposed to inconsistencies, in this case, 7 pairwise comparison matrices were verified and analyzed by the Consistency Ratio - CR, identified in table 4.

Observing the consistency ratios of the matrices corresponding to each questionnaire to the group's averages and all questionnaires, following Saaty's method (Morita [8]) it is possible to identify which ones and how many matrices of judgment were inconsistent $(\mathrm{RC}>=0,10)$. Table 5 summarizes quantitative data of these results.

Table 4: $\quad$ Consistency ratio.

\begin{tabular}{|c|c|c|c|c|c|c|}
\hline \multirow{3}{*}{$\begin{array}{l}\text { Resulting } \\
\text { judgments }\end{array}$} & \multicolumn{6}{|c|}{ Number of analyzed matrices } \\
\hline & \multirow{2}{*}{$\begin{array}{l}\text { By judgment } \\
\text { group }\end{array}$} & \multirow[b]{2}{*}{ Total } & Consistencies & \multicolumn{3}{|c|}{ Inconsistencies } \\
\hline & & & $\mathrm{CR}<0.10$ & $\begin{array}{c}0.10 \leq \mathrm{CR}<0 . \\
20\end{array}$ & $\begin{array}{c}\mathrm{CR} \geq 0.2 \\
0\end{array}$ & $\begin{array}{l}\text { Sub- } \\
\text { total }\end{array}$ \\
\hline \multirow{2}{*}{34 individuals } & \multirow{6}{*}{$\begin{array}{l}7 \text { subjected } \\
\text { to } \\
\text { inconsistenci } \\
\text { es }\end{array}$} & 238 & 94 & 59 & 85 & 144 \\
\hline & & $100 \%$ & $39 \%$ & $25 \%$ & $36 \%$ & $61 \%$ \\
\hline \multirow{2}{*}{$\begin{array}{l}13 \text { group } \\
\text { averages }\end{array}$} & & 91 & 43 & 27 & 21 & 48 \\
\hline & & $100 \%$ & $47 \%$ & $30 \%$ & $23 \%$ & $53 \%$ \\
\hline \multirow{2}{*}{$\begin{array}{l}1 \text { average of all } \\
\text { interviewed ones }\end{array}$} & & 7 & 6 & 1 & 0 & 1 \\
\hline & & $100 \%$ & $86 \%$ & $14 \%$ & $\mathbf{0 \%}$ & $14 \%$ \\
\hline
\end{tabular}

Table 5: Overall weights of the analyzed alignment alternatives.

\begin{tabular}{c|c|c|c}
\hline \multirow{2}{*}{ Segment } & \multicolumn{2}{|c|}{ Alternative } & $\begin{array}{c}\text { Result } \\
\text { (Global Weight in \%) }\end{array}$ \\
\hline \multirow{4}{*}{$\mathbf{1}$} & 1 & Green & 24.73 \\
\cline { 2 - 4 } & 2 & Red & 12.44 \\
\cline { 2 - 4 } & $\mathbf{3}$ & Lilac & $\mathbf{1 2 . 2 0}$ \\
\cline { 2 - 5 } & 4 & Orange & 50.63 \\
\hline \multirow{2}{*}{2} & 1 & Green & 22.20 \\
\cline { 2 - 5 } & $\mathbf{2}$ & Red & $\mathbf{2 0 . 9 4}$ \\
\cline { 2 - 5 } & 3 & Lilac & 29.20 \\
\cline { 2 - 5 } & 4 & Orange + Lilac & 27.66 \\
\hline \multirow{2}{*}{3} & 1 & Green & 40.38 \\
\cline { 2 - 5 } & 2 & Red & 35.28 \\
\cline { 2 - 4 } & $\mathbf{3}$ & Blue & $\mathbf{2 4 . 3 4}$ \\
\hline
\end{tabular}

Analyzing the results obtained, the great consistency presented in the individual judgment matrices (61\% of cases) was reduced to $53 \%$ of the group's average judgments. Also the results of all questionnaires average judgments showed good Consistency Ratios; only $14 \%$, where only 1 matrix was considered inconsistent. 
According to Morita [8], when the situation is inconsistent, it indicates an error of evaluation between pairs or failure of the problem structure. He affirms that AHP's recommendation to reduce high level of inconsistency is to revise related judgment matrices of pairwise comparisons.

In this paper, when a matrix resulting from interviewed members was considered inconsistent, the revision of its corresponding judgments was not possible, due to the amount of comparisons to be taken again with interviewed people. It is important to point out that judgments taken by those 34 entities interviewed resulted in 144 matrices considered inconsistent out of 238 matrices, resulting from 489 pairwise comparisons ( 375 comparisons of square matrices of third order and 114 comparisons of square matrices of fourth order).

Morita [8] considers that if inconsistency persists after reviewing judgments, two hypotheses must be considered: the relation of transitivity does not rule these factors or the knowledge about the decision factor is insufficient.

Therefore, even if judgment revision does not happen, these two hypotheses are performed, as follows:

- The first hypothesis won't appear either for criteria or indicators defined in this paper, as everyone respected transitivity relation between judgment factors (aik.akj $=$ aij). Even matrix 1, inconsistent in many cases, showed in 10 of 34 matrices $\mathrm{RC}<=0.06$;

- The second hypothesis, more reasonable, could be justified by heterogeneity and a reduced number of interviewed people.

Another justification is related to the upper limit of the factors scale of AHP (table 2) because, according to Morita [8], the upper limit by number 9 is not presented by Saaty [13] through a strong theoretical basement. The author considers that the use of this limit is more applicable due to simplicity and easy handling of operation. The effect of the upper cut can always occur, since the broad band is limited. This effect is observed when transitivity among elements close to the maximum relation, what in fact occurred in some questionnaires, specially on judgments of matrix 1 - "surface works".

So, the quantity of inconsistencies observed on table 4, were determined by the insufficient knowledge of decision factors shown by interviewed individuals and the upper limit of AHP's factors' scale. Despite these inconsistencies, these judgments were considered valid, due to the justifications presented, even the universe researched being composed by a reduced number of interviews.

\subsection{Final results}

After feeding the Expert Choice with data related to judgment of paired criteria/indicators and, after verifying the Consistency Ratio of matrices of pairwise comparisons, the software calculates the relative priorities of the group's criteria/indicator related to criteria/indicator located on the upper level (Relative Weight). Automatically, Expert Choice consolidates all weights, spreading the effect of weights on structure until the alternatives level (Overall Weight).

Having AHP's results as overall weights of alternatives related to the objective, the less heavy alternatives are more adequate. The smaller 
alternative's overall weight is, the more adequate it is, because criteria and indicators more critical received more weights in its judgments, resulting less weights to criteria and indicators less critical.

Table 5 presents overall weights of alignment alternatives to each road segments in study, related to the average judgments of all questionnaires.

For segment 1 , alternative 3 (lilac) is the most adequate, with $12.2 \%$ of Overall Weight. For segment 2, alternative 2 (red) was the most adequate, $29.94 \%$. For segment 3, alternative 3 (blue) is the most adequate, $24.34 \%$.

It is important to point that overall weights with close values indicate similarity between alternatives. This observation helps in understanding the results obtained by the model proposed and shown on table 5 . So, on segment 1 , for instance, alternative 2 , in a overall weight of $12.44 \%$, only $0.24 \%$ higher then alternative $3(12.20 \%)$. Thus, it can be considered similar enough to alternative 3 , considered the most adequate due to the criteria and indicators adopted and comparisons made. It's also relevant that, alternatives 1 and 4, overall weights $24.73 \%$ and $50.63 \%$, respectively, are even less adequate then other alternatives, due to relative differences between overall weights.

\section{Conclusions}

The results obtained for selection of alignment alternative of three segments of the Northern section of Mario Covas Ring Road indicate viability of application of the proposed model and lead to some advantages on its utilization (multicriteria evaluation $\mathrm{x}$ one-criterion evaluation).

The presented and tested methodology, using AHP, allows an evaluation of environmental impacts on a preliminary and strategic level. Therefore, the classification obtained from the alternatives by ordering their overall weights, shall indicate the decision maker (entrepreneur) which alignment alternative is the most appropriate for each road segment studied, considering economic, constructive, operational and traffic safety aspects, not to mention the environmental ones, as well as the "distancing" from the other alternatives.

Through the results obtained by interviews with many actors of society, environmental aspects were considered as the most critical and relevant in the study of alignment alternatives analyzed. With an overall weight higher than $50 \%$, as a result of all questionnaires judgment's average, environmental aspects are still the most relevant to society as a whole, when it comes to a road enterprise, as the Northern section of the Ring Road. So, the recommended alignment alternative shows less critical environmental impacts. This result leads, in this case, that opinion of many sectors of society differs from group's opinion that commonly make decisions (government technicians, consultants, and other), demonstrating the importance and need of participative planning in this kind of study.

The application of the proposed model, characterized by society's participation and adoption of multicriteria showing each alternative, fits as a document basis of decision making process. So, the indication of the most adequate alternative to implantation on this phase happens through the model 
(interviews' tabulation, Expert Choice's simulation, etc). The main reason for adoption of this method in this kind of study is that multidisciplinary decisions can be made on a documented quantitative basis. The different actor's opinions involved on the project are reflected on the analysis through criteria/indicator's weights.

It can be considered that the adopted process for helping decision-making, Analytic Hierarchy Method - AHP, shows a strong dependence on problem's structuring stage. A great part of the problem's resolution is not on the evaluation stage, but on matrix fulfillment through pair wise judgments of criteria/indicators. Criteria and indicators definition and structure and alternative's definition are extremely important in the decision making process, that once coherently established, won't let doubts to judgment's realization by interviewed individuals. Consequently, the probability of inconsistent judgments is reduced.

New researches in progress intend to use an interactive method to extend the proposed model capacity, for instance, by using a new version of Expert Choice. This way, some judgment's inconsistencies observed on this study case certainly won't happen, because some judgments considered inconsistent will be reviewed interactively. Moreover, the judgment's results will be presented to the interviewed individuals in real time, making the classification process and alignment alternatives selection for urbanized crossing highways even more efficient and trustable.

Finally, the proposed model can be considered as a contribution for decision making, first, as a preliminary and strategic tool for classification and selection of highway's alignment alternatives. Having the model's result and analysis, the decision maker (entrepreneur) can consider that a coherent technical decision is being proposed with representing groups of society in agreement.

\section{References}

[1] DERSA, Rodoanel Metropolitano de Sao Paulo - Trecho Norte: Estudo Funcional de Alternativas de Traçado, Planservi Engenharia Ltda, Sao Paulo, 1999.

[2] Expert Choice, User manual, RWS, Pittsburgh, 1995.

[3] Gomes, L.F.A.M. \& Lima, M.M.P.P., TODIM: Basics and Application to Multicriteria Ranking of Projects with Environmental Impacts, Foundations of Computing and Decision Sciences, v.16, pp.113-127, 1991.

[4] Kalamaras, G.S., Brino, L., Carrieri, G., Pline C. \& Grasso, P., Application of Multicriteria Analysis to Select the Best Highway Alignment, Tunnelling and Underground Space Technology, v.15, n.4, pp.415-420, 2000.

[5] Lisboa, M. V., Contribuição para a Tomada de Decisão na Classificação e Seleção de Alternativas de Traçado para Rodovias em Trechos Urbanizados, POLI-USP, São Paulo, 2002. 
[6] Lopez, J.A.U., Estudos e Relatórios de Impacto Ambiental: Aspectos Práticos. Anais do $1^{\circ}$ Seminário Nacional: A Variável Ambiental em Obras Rodoviárias, FUPEF, Foz do Iguaçu, p.15-38, 1999.

[7] Mccormack, S., Agents of Change. World Highways, v.10, n.3, p.32-34, 2001.

[8] Morita, H., Revisão do Método de Análise Hierárquica - MAH (AHP Analytic Hierarchy Process), POLI-USP, São Paulo, 1998.

[9] Palhares, G. L., Avaliação de Alternativas de Transporte no Corredor Rio de Janeiro-Niterói-São Gonçalo-Itaboraí: O Método da Análise Hierárquica Multicriterial, PET/COPPE/UFRJ, Rio de Janeiro, 2000.

[10] Passounneau, J.R., Gunnerson C.G., Miller D.R., Environmental Engineering, In: Baker, R. F. Handbook of Highway Engineering. Van Nostrand Reinhold, New York, 1975.

[11] Rabbani, S.J.R., Rabbani S.R., Decisions in Transportation with the Analytic Hierarchy Process, Ricardo Bezerra, Campina Grande, 1996.

[12] Ramanathan, R., A Note on the Use of the Analytic Hierarchy Process for Environmental Impact Assessment, Journal of Environmental Management, v63, p.24-35, 2001.

[13] Saaty, T. L., The Analytic Hierarchy Process: Planning, Priority Setting, Resource Allocation, McGraw-Hill, New York, London, 1980.

[14] Zhu, X., Dale A.P., Java AHP: a Web-Based Decision Tool for Natural Resource and Environmental Management. Environmental Modelling \& Software, v.16, p.251-262, 2001. 